\title{
PENELITIAN PENGGUNAAN TENAGA KERJA PADA INDUSTIRI \\ PERKULITAN INDONESIA TAHUN 1986-1990 DAN PROYEKSI \\ UNTUK TAHUUN 1991-1995
}

Oleh : Tisnowati, Titik Purwati Widowati, Joko Suranto

\section{ABSTRACT}

The aim of this study was to observe the description of the leather industry labour's condition in medium and large scale during 1986-1990 and its proyection during 1991-1995 period. In this study is discussed about the quantity of the industry, the quantity and type of labour and expenses spent for them in each types leather industries respectively. The quantity of the leather industry, quantity of labour and expenses spent for them increasing every year during that period. Sharing of the three types in leather industry moved although the most contribution settled be dominated by footwear manufacturing. In 1990 , footwear manufacturing had sharing $62,85 \%$ in quantity of the industry but they may absorb $80,43 \%$ labour and spent $90,8 \%$ expenses of the leather industry proyection. In 1995, this industry have sharing $64,70 \%$, absorb $82,06 \%$ labour and spent $90,93 \%$ expenses of the leather industry. The result of this study conclude that the skilled labour absolute be needed for developing of the leather industry in the future.

\section{INTISARI}

Penelitian ini bertujuan untuk memperoleh gambaran tentang keadaan ketenaga-kerjaan industri perkulitan Indonesia skala besar dan sedang tahun 1986-1990 dan proyeksinya antara tahun 1991-1995. Pada penelitian ini dibahas jumlah perusahaan, banyak dan jenis tenaga kerja serta pengeluaran untuk tenaga kerja pada masing-masing jenis industri perkulitan. Jumlah perusahaan, banyak tenaga kerja serta pengeluaran tenaga kerja untuk ke tiga jenis industri perkulitan tersebut terus meningkat setiap tahunnya. Peranan ketiga jenis industri perkulitan pun mengalami pergeseran walaupun peranan terbesar masih tetap didominasi oleh jenis industri barang-barang keperluan kaki dari kulit dan kulit imitasi. Pada tahun 1990 jumlah perusahaan industri barang-barang keperluan kaki dari kulit dan kulit imitasi menyumbang peran $62,85 \%$, namun mampu menyerap $80,43 \%$ tenaga dan membutuhkan pengeluaran $90,48 \%$ dari sektor industri perkulitan. Pada tahun 1995 industri ini diproyeksikan menyumbang peran 64,70\% dari jumlah usaha, menyerap tenaga kerja $82,06 \%$ serta membutuhkan pengeluaran $90,93 \%$ dari sektor industri perkulitan. Dari pembahasan yang dilakukan diperoleh kesimpulan bahwa tersedianya tenaga trampil akan sangat diperlukan untuk pengembangan industri perkulitan di tahun-tahun mendatang.

Vol IX No. 18 Tahun 1993/1994 


\section{PENDAHULUAN}

Perluasan kesempatan kerja merupakan salah satu sasaran utama pembangunan. Pekerjaan bukan hanya memberikan penghasilan tetapi juga meningkatkan harkat dan martabat. Kebijaksanaan di bidang ini diarahkan untuk mendorong kegiatan-kegiatan pembangunan yang dapat menciptakan lapangan kerja baru dengan produktifitas yang semakin meningkat bagi angkatan kerja.

Untuk itu pertumbuhan ekonomi yang memadai harus dicapai, terutama di sektor-sektor yang menyerap banyak tenaga kerja. Sektor industri pengolahan merupakan salah satu sektor industri yang diharapkan banyak menyerap tenaga kerja tersebut.

Industri perkulitan di Indonesia adalah industri pengolahan yang bersifat padat karya (labour intensive industri) dan berpotensi untuk dikembangkan sejalan dengan kebijaksanaan pemerintah dalam hal usaha peningkatan penerimaan sektor non migas (anonim,1993)

Menurut Samoelson (1991), begitu berkembangnya perekonomian, segala sesuatu tentang kerja akan lebih terspesialisasi. Tenaga kerja akan teralokasi menjadi bidang-bidang pekerjaan yang lebih kecil yang juga lebih membutuhkan ketrampilan semakin tinggi. Semakin luas tingkat persaingan ang dihadapi suatu produk, semakin besar tingkat ketrampilan yang dibuuhkan untuk menghasilkan produk tersebut. Hal tersebut akan mempengauhi kebijaksanaan pabrik/usaha dalam penerimaan pegawainya. Di lain pilak semakin tinggi tingkat ketrampilan/kemampuan tenaga kerja akan memutuhkan pengeluaran (upah) yang semakin besar pula.

Sehubungan dengan itu penelitian ini bertujuan untuk mengetahui bayak dan jenis tenaga kerja serta pengeluaran untuk tenaga kerja pada sektor ndustri perkulitan Indonesia skala besar dan sedang, dalam periode 1986 990, dan proyeksinya untuk tahun 1991-1995.

Menurut BPS (1988), perusahaan-perusahaan industri skala besar dan edang adalah industri yang mempunyai tenaga kerja 20 orang atau lebih, aik menggunakan mesin tenaga atau tidak.

\section{MATERI DAN METODA}

\section{Materi}

Untuk melaksanakan penelitia ı ini dibutuhkan materi data sebagai berikut :

a. Banyaknya perusahaan perkulitan skala besar dan sedang di Indonesia, tahun 1986-1990. b. Banyaknya tenaga kerja yang bekerja pada industri perkulitan skala besar dan sedang di Indonesia, tahun 1986-1990.

c. Jenis tenaga kerja, menurut pembayaran upah dan penggunaan tenaga kerja.

d. Banyaknya pengeluaran untuk tenaga kerja.

\section{2. Metode}

a. Data diambil dari statistik industri tahun 1986-1990. Data disusun menurut tahun kejadian, klasifikasi industri, banyak perusahaan, jenis tenaga kerja dan banyaknya pengeluaran

b. Data diproyeksikan selama lima tahun antara tahun 1991-1995.

\section{UI. HASIL DAN PEMBAHASAN}

Industri perkulitan di Indonesia, berdasar deskripsi komoditinya dapat digolongkan kedalam tiga bagian lapangan usaha yaitu :

1. Industri penyamakan dan pengolahan kulit.

2. Industri barang-barang dari Kulit dan Kulit Imitasi/buatan.

3. Industri Barang-barang Keperluan Kaki dari Kulit dan Kulit Imitasi/ buatan.

Pada tabel 1 dapat dilihat perkembangan penggunaan tenaga kerja pada industri penyamakan dan pengolahan kulit skala besar dan sedang tahun 1986 - 1990, sedang tabel 2 berisi proyeksi penggunaan tenaga kerja pada industri penyamakan dan pengolahan kulit skala besar dan sedang tahun 1991 - 1995.

Banyakanya perusahaan industri penyamakan dan pegolahan kulit skala besar dan sedang meningkat setiap tahunnya kecuali pada tahun 1987 terjadi penurunan 5 perusahaan $(9,40 \%)$ dibanding jumlah perusahaan industri penyamakan dan pengolahan kulit tahun sebelumnya (1986). Secara keseluruhan antara tahun 1986 - 1990 terjadi peningkatan rata - rata jumlah perusahaan sebesar $5,80 \%$ pertahunnya. Apabila dilihat perkembangannya lima tahun sekaligus jumlah perusahaan industri penyamakan dan pengolahan kulit skala besar dan sedang ini meningkat $24,50 \%$ 
Tabel 1 : Perkembangan Penggunaan Tenaga Kerja Pada Industri Penyamakan dan Pengolahan Kulit Skala Besar dan Sedang Tahun 1986 - 1990

\begin{tabular}{|c|c|c|c|c|c|c|c|c|c|c|c|c|}
\hline No & Uraian & 1986 & 1987 & $\begin{array}{l}\text { \%per } \\
\text { kemb }\end{array}$ & 1988 & $\begin{array}{l}\text { \%per } \\
\text { kemb }\end{array}$ & 1989 & $\begin{array}{l}\text { \%per } \\
\text { kemb }\end{array}$ & 1990 & $\begin{array}{c}\text { \%per } \\
\text { Lemb }\end{array}$ & 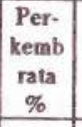 & \begin{tabular}{|c|} 
Per- \\
kemb \\
Sth \\
$(\%)$ \\
\end{tabular} \\
\hline \multirow[t]{5}{*}{$\begin{array}{l}1 . \\
2 .\end{array}$} & $\begin{array}{l}\text { Banyaknya } \\
\text { Perusahaan } \\
\text { Banyaknya Te- } \\
\text { naga } \\
\text { a. Tenaga Kerja }\end{array}$ & 53 & 48 & $-9,4$ & 53 & 9,4 & 58 & 9,4 & 66 & 13,8 & 5,8 & 24,5 \\
\hline & $\begin{array}{l}\text { Dibayar: } \\
\text { a.1. Tenaga } \\
\text { Kerja Pro }\end{array}$ & 3183 & 3.378 & 6,1 & 4.050 & 19,9 & 5063 & 25,0 & 7.339 & 44,9 & 23,9 & 130,6 \\
\hline & $\begin{array}{l}\text { duksi (org } \\
\text { a.2. Tenaga } \\
\text { Kerja Lain }\end{array}$ & 2705 & 2906 & 7,4 & 3.452 & 18,8 & 4.251 & 23,1 & 6.410 & 50,9 & 25,1 & 137,3 \\
\hline & nya & 478 & 472 & $-1,3$ & 598 & 26,7 & 812 & 35,8 & 920 & 13,3 & 18,6 & 92,5 \\
\hline & thas & 42. & 26 & $-38,1$ & 43 & 65,4 & 39 & $-9,3$ & 31. & $-20,5$ & $-0,6$ & $-26,2$ \\
\hline 4. & $\begin{array}{l}\text { c. Jumlah }(a+b) \\
\text { Pengeluaran un- } \\
\text { tuk kerja }\end{array}$ & 3225 & 3404 & 5,6 & 4.093 & 20,2 & 5.102 & 24,7 & 7.370 & 44,5 & 23,8 & 128,5 \\
\hline & & $2.569,2$ & $3.345,6$ & 30,1 & $4.454,7$ & 43,2 & $5.800,4$ & 30,2 & $3.269,2$ & 42,6 & 36,5 & 221,9 \\
\hline
\end{tabular}

Sumber : diolah dari Statistik Industri Indonesia tahun 1986,1987,1988, 1989,1990 Biro Pusat Statistik

Tabel 2 : Proyeksi Penggunaan Tenaga Kerja pada Industri Penyamakan dan Pengolahan Kulit Skala Besar dan Sedang untuk Tahun 1991-1995

\begin{tabular}{|l|l|r|r|r|r|r|}
\hline No & \multicolumn{1}{|c|}{ Uraian } & \multicolumn{1}{c|}{1991} & 1992 & \multicolumn{1}{c|}{1993} & 1994 & \multicolumn{1}{c|}{1995} \\
\hline 1. & Banyaknya & 66 & 70 & 74 & 77 & 81 \\
2. & $\begin{array}{l}\text { Perusahaan (bh) } \\
\text { Banyaknya } \\
\text { Tenaga Kerja } \\
\text { (org) } \\
\text { 3. }\end{array}$ & 7.635 & 8.634 & 10.632 & 10.632 & 11.630 \\
$\begin{array}{l}\text { Pengeluaran } \\
\text { untuk tenaga } \\
\text { kerja (juta Rp.) }\end{array}$ & $9.044,26$ & $10.429,74$ & $13.200,7$ & $13.200,7$ & $14.586,18$ \\
\hline
\end{tabular}

Sejalan dengan peningkatan jumiah perusahaan industri penyamakan dan pengolahan kulit, jumlah tenaga kerja yang dipergunakan industri terebut semakin meningkat pula, dari jumlah 3.225 orang pada tahun 1986 menjadi 7.370 orang pada tahun 1990 atau meningkat sebesar $128,50 \%$.

Majalah Barang Kulit, Karet dan Plastik
Jumlah tenaga kerja rata-rata yang dipergunakan oleh setiap perusahaan industri tersebut meningkat pula. Pada tahun 1986 rata-rata setiap perusahaan penyamakan dan pengolahan kulit menggunakan jasa 60,85 orang, pada tahun 1987 sebesar 70,92 orang; tahun 1988 sebesar 77,23 orang ; tahun 1989 sebesar 87,99 orang dan tahun 1990 sebesar 111,67 orang

Semakin besar rata-rata penggunaan tenaga kerja pada setiap perusahaan berarti semakin besar usaha industri tersebut yang biasanya juga semakin besar jumlah produk yang dihasilkan oleh perusahaan industri.

Jumlah pengeluaran pengeluaran untuk tenaga kerjapun meningkat sebesar $221,9 \%$ dari Rp. $2.569,20$ juta pada tahun 1986 menjadi Rp. $8.269,20$ juta pada tahun 1990 Namun apabila dilihat dari jumlah rata-rata pengeluaran pertenaga kerja, hanya meningkat sebesar $41,80 \%$ dari sebesar Rp. $796.651,16 /$ orang per tahun (1986) menjadi Rp. 1.122.088,14 (1990) sedang rata-rata pengeluaran per tenaga kerja tahun 1987 sebesar Rp. 982.843,71; meningkat terus menjadi Rp. 1. 088.370,38 (1988) dan Rp. 1.136.887,47 (1989) perorang.

Hal tersebut menunjukan semakin meningkatnya angkatan kerja yang terserap industri ini sejalan dengan bertambahnya pengeluaran untuk tenaga kerja. Namun peningkatan pendapatan rata-rata per tenaga kerja tidak sebanding dengan peningkatan pengeluaran industri untuk upah semua tenaga. Adanya fenomena seperti tersebut diatas menunjukan bahwa bidang industri ini lebih banyak menyerap angkatan kerja sektor bawah (tenaga kasar) dari pada tenaga tingkat trampil (skilled employment).

Perkembangan penggunaan tenaga kerja pada industri barang-barang kulit dan kulit imitasi sekala besar dan sedang tahun 1986-1990 dapat dilihat pada tabel 3. Sedang proyeksi penggunaan tenaga kerja industri barang-barang kulit imitasi tahun 1991-1995 dapat dilihat pada tabel 4.

Jumlah perusahaan industri barang-barang kulit dan kulit imitasi skala besar dan sedang tahun 1986-1990 meningkat sebesar $93,9 \%$.

Pengeluaran untuk tenaga kerja pada industri barang-barang kulit dan imitasi skala besar antara tahun 1986 sampai tahun 1990 meningkat setiap tahunnya. Peningkatan ini diimbangi pula dengan peningkatan pengeluaran rata-rata per tenaga kerja per tahun, yaitu sebesar Rp. 704.337,50 (1986); Rp. 698.152,17 (1987); Rp. 830.824,80 (1988); Rp. 946.633,55 (1989) dan Rp. $1.139 .942,68(1990)$.

Vol IX No. 18 Tahun 1993/1994 
Tabel 3 : Perkembangan Penggunaan Tenaga Kerja Pada Industri Barangbarang dari Kulit dan Kulit Imitasi Skala Besar dan Sedang Tahun 1986 . 1990

\begin{tabular}{|c|c|c|c|c|c|c|c|c|c|c|c|c|}
\hline No & Uraian & 1986 & 1987 & $\left|\begin{array}{l}\% \text { per } \\
\text { kemb }\end{array}\right|$ & 1988 & $\begin{array}{l}\text { \%per } \\
\text { kemb }\end{array} \mid$ & 1989 & $\begin{array}{l}\% \text { per } \\
\text { keab }\end{array}$ & 1990 & $\left|\begin{array}{l}\% \text { per } \\
\text { kemb }\end{array}\right|$ & \begin{tabular}{|c|}
$\begin{array}{c}\text { Per- } \\
\text { kemb } \\
\text { rata }^{2} \\
\%\end{array}$ \\
\end{tabular} & \begin{tabular}{|c|}
$\begin{array}{c}\text { Per- } \\
\text { kemb } \\
\text { rata }^{2} \\
\% \\
\end{array}$ \\
\end{tabular} \\
\hline \multirow[t]{6}{*}{$\begin{array}{l}1 . \\
2 .\end{array}$} & $\begin{array}{l}\text { Banyaknya } \\
\text { Perusahaan } \\
\text { Banyaknya Te- } \\
\text { naga } \\
\text { a. Tenaga Kerja }\end{array}$ & 23 & 23 & 0 & 31 & 34,8 & 33 & 6,5 & 64 & 93,9 & 33,8 & 178,3 \\
\hline & $\begin{array}{l}\text { Dibayar: } \\
\text { a.1. Tenaga } \\
\text { Kerja Pro- }\end{array}$ & 774 & 870 & 12,4 & 1.631 & 87,5 & 1.786 & 9,5 & 5,514 & 208,7 & 79,5 & 612,4 \\
\hline & $\begin{array}{ll}\text { duksi (org } \\
\text { a.2. Tenaga } \\
\text { Kerja Lain }\end{array}$ & 703 & 787 & 11,9 & 1.439 & 82,8 & 1.540 & 7,0 & 4.997 & 224,5 & 81,6 & 610,8 \\
\hline & & 71 & 83 & 16,9 & 192 & 131,3 & 246 & 28,1 & 517 & 110,2 & 71,6 & 628,2 \\
\hline & Dibayar & 33 & 50 & 51,5 & 30 & -40 & 26 & $\mid-13,3$ & 69 & 165,4 & 40,9 & 109,1 \\
\hline & c. Jumlah $(\mathrm{a}+\mathrm{b})$ & 807 & 920 & 14,0 & 1.661 & 80,5 & 1.812 & 9,1 & 5.583 & 208,1 & 77,9 & 591,8 \\
\hline 4. & (juta Rp) & 568,4 & 642,3 & 13,0 & $1.380,0$ & 114,9 & 1.715 & 24,3 & $6.364,3$ & 27 & 103 & 97 \\
\hline
\end{tabular}

Sumber : diolah dari Statistik Indonesia tahun 1986, 1987, 1988, 1989, 1990 Biro Pusat Statistik

Tabel 4 : Proyeksi Penggunaan Tenaga Kerja pada Industri Barang-barang dari kulit dan kulit ifmitasi Skala besar dan sedang tahun 1991 - 1995

\begin{tabular}{|l|l|r|r|r|r|r|}
\hline No & \multicolumn{1}{|c|}{ Uraian } & \multicolumn{1}{c|}{1991} & \multicolumn{1}{c|}{1992} & \multicolumn{1}{c|}{1993} & \multicolumn{1}{c|}{1994} & \multicolumn{1}{c|}{1995} \\
\hline 1. & Banyaknya & 62 & 72 & 81 & 90 & 99 \\
2. & $\begin{array}{l}\text { Perusahaan } \\
\text { (bh) }\end{array}$ & 5.261 & 6.295 & 7.330 & 8.365 & 9.399 \\
$\begin{array}{l}\text { Banyaknya } \\
\text { Tenaga Kerja } \\
\text { (org) } \\
\text { 3. }\end{array}$ & $\begin{array}{l}\text { Pengeluaran } \\
\text { untuk tenaga } \\
\text { kerja (juta Rp.) }\end{array}$ & $5.933,35$ & $7.199,8$ & $8.466,25$ & $9.732,7$ & $10.99,158$ \\
\hline
\end{tabular}

Besarnya pengeluaran untuk tenaga kerja merupakan besarnya dana baik berupa uang atau barang, yang dikeluarkan perusahaan untuk para pekerjanya. Dengan demikian semakin besar dana perusahaan yang dikeluarkan akan dapat meningkatkan pendapatan pekerjaannya, disamping membuka kesempatan lapangan pekerjaan. Semakin besar pendapatan perkapita tenaga diharapkan kesejahteraan tenaga kerja tersebut semakin meningkat.

Pada tahun 1990, pendapatan pertenaga kerja per tahun pada industri barang kulit dan kulit imitasi meningkat cukup dibanding pendapatan pada tahun-tahun sebelumnya.

Seperti halnya industri penyamakan dan pengolahan kulit serta industri barang-barang kulit dan kulit imitasi jumlah perusahaan pada industri barang-barang keperluan kaki dari kulit dan kulit imitasipun meningkat setiap tahunnya. Antara tahun 1986/1990 terjadi peningkatan 105 perusahaan, dari 115 perusahaan di tahun 1986 menjadi 220 perusahaan pada tahun 1990.

Peningkatan jumlah perusahaan ini diikuti pula dengan peningkatan jumlah tenaga kerja yang sangat besar, dari sebesar 8.695 orang di tahun 1986 menjadi 53.221 orang di tahun 1990 atau meningkat sebesar 512,10 \%. Peningkatan jumlah tenaga kerja yang besar ini mengakibatkan rata-rata penggunaan tenaga kerja per perusahaan meningkat pula dari 75,69 orang/perusahaan (1986-1987) ; 106,26 orang/perusahaan (1988); 157,15 orang/perusahaan (1989) menjadi 241,91 orang/perusahaan di tahun 1990.

Seperti pada industri terdahulu pengeluaran untuk tenaga kerja pada industri barang-barang keperluan kaki dari kulit dan kulit imitasi skala besar dan sedang pun meningkat setiap tahunnya dari sebesar Rp. 10.653,60 Juta pada tahun 1986; Rp. 12.463,70 juta (1987); Rp. 25.133,90 juta (1988); Rp. $36.097,20$ juta (1989) dan Rp. 148.682,70 juta pada tahun 1990.

Dengan demikian antara tahun 1986-1990 terjadi peningkatan pengeluaran untuk tenaga kerja jenis industri ini sebesar $1.295,6 \%$ atau rata-rata sebesar $114,4 \%$ per tahun.

Peningkatan Pengeluaran untuk tenaga kerja ini diikuti pula dengan peningkatan rata-rata pengeluaran untuk setiap tenaga kerja, dari sebesar Rp. 1. 225.225, 89/orang pada tahun 1986; meningkat menjadi Rp. 1,430.450,82 (1987); Rp, 1.587.437,76/orang (1988); Rp. 1.431.056,15/orang (1989) dan menanjak menjadi Rp. 2.793.684,82/orang di tahun 1990.

Pengeluaran rata-rata per tenaga kerja jenis industri barang-barang keperluan kaki ini sangat jauh di atas jenis industri perkulitan lainnya. Pada tahun 1990 pengeluaran per tenaga kerja telah melampaui Rp. $2.000 .000 /$ tahun. Gambaran tersebut menunjukkan salah satu indikasi bahwa jenis industri ini talah banyak memerlukan tenaga terampil yang membutuhkan banyak 
biaya dibanding jenis industri perkulitan lainnya.

Perkembangan penggunaan tenaga kerja pada industri barang-barang keperluan kaki dari kulit dan kulit imitasi skala besar dan sedang antara tahun 1986 - 1990 dapat dilihat pada tabel 3

Tabel 5 : Perkembangan Penggunaan Tenaga Kerja Pada Industri Barang-Barang Keperluan Kaki Skala Besar dan Sedang Tahun 1986-1990

\begin{tabular}{|c|c|c|c|c|c|c|c|c|c|c|c|c|}
\hline No & Uraian & 1986 & 1987 & $\begin{array}{l}\% \text { per } \\
\text { kemb }\end{array}$ & 1988 & $\begin{array}{l}\% \text { per } \\
\text { kemb }\end{array}$ & 1989 & $\begin{array}{l}\% \text { per } \\
\text { kemb }\end{array}$ & 1990 & $\left|\begin{array}{l}\% \text { per } \\
\text { lemb }\end{array}\right|$ & \begin{tabular}{|c|}
$\begin{array}{c}\text { Per- } \\
\text { kemb } \\
\text { rata } \\
\%\end{array}$ \\
\end{tabular} & 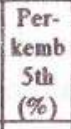 \\
\hline \multirow[t]{6}{*}{1.} & $\begin{array}{l}\text { Banyaknya } \\
\text { Perusahaan } \\
\text { Banyaknya Te- } \\
\text { naga } \\
\text { a. Tenaga Kerja }\end{array}$ & 115 & 115 & 0 & 149 & 29,6 & 160 & 7,4 & 220 & 37,5 & 18,6 & 91,3 \\
\hline & $\begin{array}{l}\text { Dibayar: } \\
\text { a.1. Tenaga } \\
\text { Kerja Pro- }\end{array}$ & 8.577 & 8.594 & 0,2 & 15.64 & 82,0 & 25.078 & 60,3 & 53,042 & 111,8 & 63,5 & 518,4 \\
\hline & $\begin{array}{l}\text { duksi (org) } \\
\text { a.2. Tenaga } \\
\text { Kerja Lain }\end{array}$ & 7.390 & 7.379 & $-0,1$ & 13.96 & 89,2 & 23.010 & 64,8 & 49.014 & 113,0 & 66,7 & 563,2 \\
\hline & $\begin{array}{r}\text { nya (org) } \\
\text { b. Tenaga Kerja }\end{array}$ & 1.187 & 1.215 & 2,4 & $1.67 \%$ & 38,2 & 2063 & 23,2 & 4.028 & 94,014 & 39,7 & 239,3 \\
\hline & Dibayar & 118 & 110 & $-6,8$ & 192 & 74,5 & $14 d$ & $-23,9$ & 179 & 22,6 & 16,6 & 51,7 \\
\hline & c. Jumlah $(a+b)$ & 8.695 & 8.704 & 0,1 & 15.883 & 81,9 & 25.224 & 59,3 & 53,221 & 110,9 & 63,05 & 512,1 \\
\hline 8. & $\begin{array}{l}\text { tuk kerja } \\
\text { (juta Rp) }\end{array}$ & $10.653,6$ & $12.468,7$ & 0,2 & 25.133, & 101,7 & $36.097,2$ & 43,6 & $148,682,7$ & 311,9 & 114,4 & $.295,6$ \\
\hline
\end{tabular}

Sumber : diolah dari Statistik Industri Indonesia tahun 1986, 1987, 1988, 1989, 1990 Biro Pusat Statistik

Tabel 6: Proyeksi Penggunaan Tenaga kerja pada Industri Barang-barang keperluan kaki skala besar dan sedang tahun 1991-1995

\begin{tabular}{|c|c|c|c|c|c|c|}
\hline No & Uraian & 1991 & 1992 & 1993 & 1994 & 1995 \\
\hline 1. & Banyaknya & 228 & 254 & 74 & 77 & 81 \\
\hline 2. & $\begin{array}{l}\text { Perusahaan } \\
\text { (bh) } \\
\text { Banyaknya } \\
\text { Tenaga Kerja } \\
\text { (org) }\end{array}$ & 54.017 & 64.574 & 10.632 & 10.632 & 11.630 \\
\hline 3. & $\begin{array}{l}\text { Pengeluaran } \\
\text { untuk tenaga } \\
\text { kerja (juta } \mathrm{Rp} \text {.) }\end{array}$ & $136.513,23$ & $166.481,9$ & $13.200,7$ & $13.200,7$ & $14.586,18$ \\
\hline
\end{tabular}

Dilihat perkembangan peranan masing-masing jenis industri perkulitan terjadi pergeseran peranan dalam selama lima tahun antara tahun 19861990.

Pada tahun 1986, jumlah perusahaan industri penyamakan dan pengolahan kulit mempunyai peran sebesar $27,75 \%$; industri barang-barang kulit dan kulit imitasi $12,04 \%$ dan industri barang-barang keperluan kaki 60,29\%. Pada tahun 1990 peranan industri penyamakan dan pengolahan kulit semakin berkurang tinggal menjadi $18,86 \%$. Berkurangnya peran industri tersebut diikuti pula dengan semakin meningkatnya peran kedua jenis industri perkulitan lainnya masing-masing menjadi $18,29 \%$ untuk industri barangbarang kulit dan kulit imitasi serta $62,85 \%$ untuk industri barang-barang keperluan kaki dari kulit dan kulit imitasi.

Berkembangnya peran jumlah perusahaan industri penyamakan dan pengolahan kulit ini di ikuti pula oleh berkembang peranan (pada) jumlah tenaga kerja. Dari gambar 1 didapat gambaran bahwa pada tahun 1990 industri barang-barang keperluan kaki maupun menyerap $80,43 \%$ jumlah tenaga kerja sektor industri perkuliian. Ditinjau perkembagannya dari tahun ke tahun jenis industri ini masih besar kemungkinannya terus berkembang. Berkembangnya jenis industri ini sangat berpotensi untuk menyerap angkatan kerja yang ada di masyarakat.

Berdasarkan hasil pembahasan sebelummnya juga ditinjau dan besarnya peran pengeluaran/dana untuk tenaga kerja peट́ jenis industri barangbarang keperluan kaki dari kulit dan kulit imitasi. Pada tahun-tahun mendatang angkatan kerja yang dibutuhkan jenis industri ini adalah tenaga yang telah mempunyai ketrampilan khusus. Dengan demikian sebelum tenaga tersebut terjun di lapangan diharapkan telah memperoleh cukup pengetahuan dalam bidangnya dapat melalui kursus-kursus atau pendidikan formal lainnya. Tersediannya tenaga yang berketrampilan ini mutlak untuk menunjang terus berkembangnya jenis industri yang handal.

Dari hasil proyeksi pertambahan jumlah industri perkulitan Indonesia tahun 1991-1995 akan semakin meningkat, demikian juga jumlah dan pengeluarannya tenaga kerja.

Pada tahun 1995 jumlah industri perkulitan Indonesia skala besar dan sedang diperkirakan 510 buah, yang meliputi industri penyamakan dan peng olahan kulit 81 buah, industri barang-barang dari kulit dan kulit imitasi 99 buah dan industri barang-barang keperiuan kaki dari kulit dan kulit imitas 330 buah. Yang berarti jumlah industri barag-barang keperluan kaki pada tahun tersebut akan menyumbang peran sebesar $64,70 \%$. Pada saat itu jumlah tenaga kerja yang dipergunakan pada industri perkulitan Indonesia diperkirakan sebesar 47.275 orang dengan industri barang-barang keperluan kaki

Vol IX No. 18 Tahun 1993/1994 
tampu menyerap 96.246 orang atau $82,06 \%$.

ada tahun 1995 tersebut diperkirakan pengeluaran tersebar juga didominasi leh industri barang-barang keperluan kaki yakni sebesar $90,93 \%$ dari total engeluaran untuk tenaga kerja sektor industri perkulitan Indonesia dengan engeluaran rata-rata per tahun per tenaga kerja sebesar Rp. 2.663.881,20 ang berarti diatas upah rata-rata pekerja Indonesia yang hanya sebesar Rp. 2 juta/orang tahun.

\section{KESIMPULAN}

Sejalan dengan meningkatnya jumlah perusahaan industri perkulitan pada tahun 1986-1990, kebutuhan tenaga kerja dan pengefuaran untuk membiayainya semakin meningkat pula.

Antara tahun 1986-1990 terjadi pergeseran peranan jenis industri perkulitan, walaupun peranan terbesar tetap didominasi oleh jenis industri barang-barang keperiuan kaki dari kulit dan kulit imitasi/buatan.

Pada tahun 1990 peranan jumlah perusahaan industri barang-barang eperluan kaki sebesar $62,85 \%$ yang mampu menyerap $80,43 \%$ tenaga kerja mengeluarkan anggaran untuk tenaga kerja $90,84 \%$ dari sektor industri erkulitan.

Pada tahun 1995 industri barang-barang keperluan kaki dari kulit dan lit imitasi menyumbang peran $64,70 \%$ dari jumlah usaha, menyerap tega kerja $82,06 \%$ serta membutuhkan pengeluaran $90,93 \%$ dari sektor inustri perkulitan

Tersedianya tenaga yang mempunyai ketrampilan akan semakin dibuhkan pada tahun-tahun mendatang.

\section{DAFTAR PUSTAKA}

Anonim (1993) : Prospek Industri Perkulitan dalam Era Pembangunan Jangka Panjang Tahap II ; Proc. Simposium Nasional Perkulit- an 1993, Yogyakarta

Biro Pusat Statistik tahun 1986; 1987; 1988; 1989; 1990, Statistik Industri Indonesia.

Samueison, Paul A. and Nordhaus, William D (1991); Penerbit Erlangga Surabaya. 